
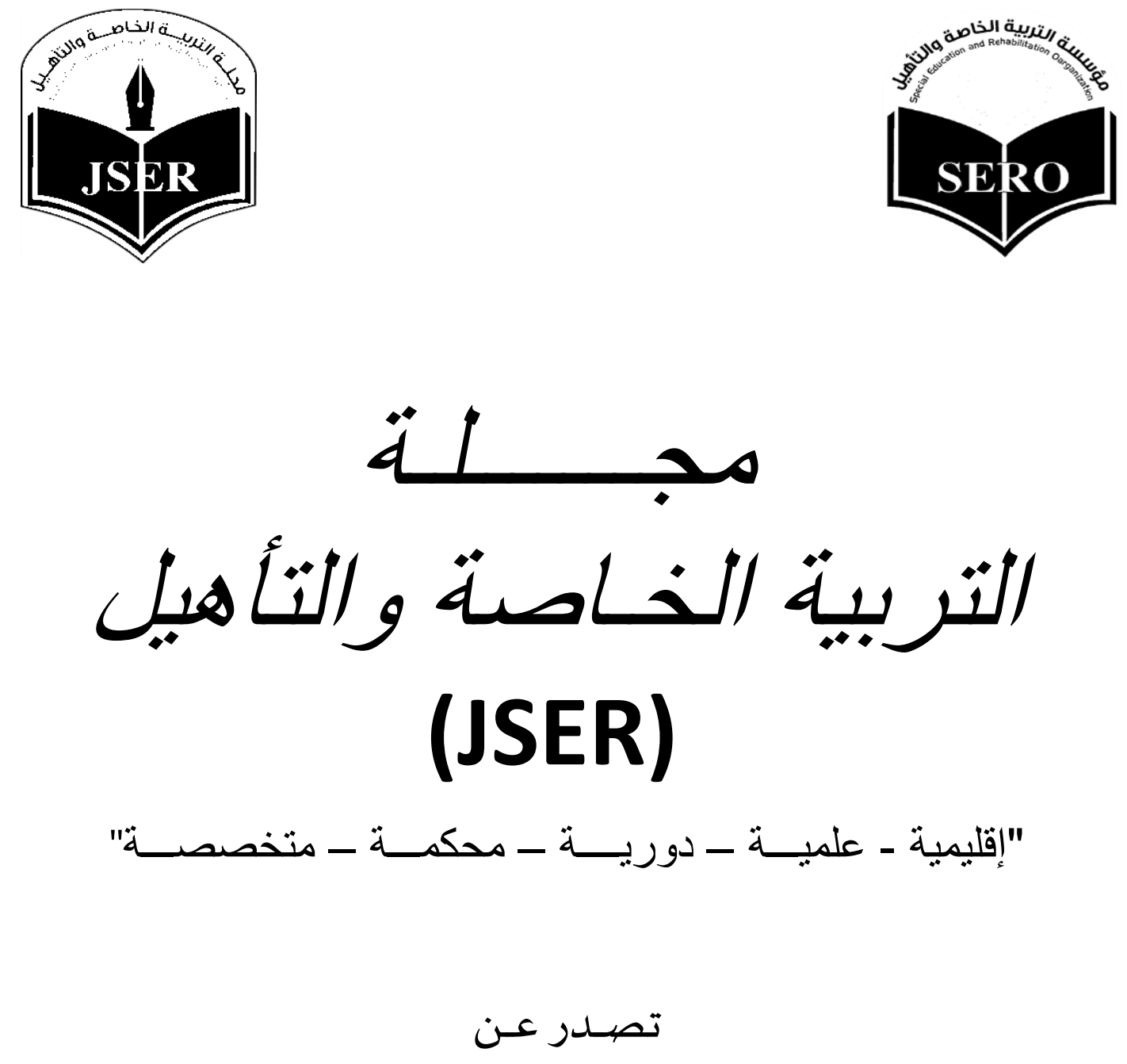

مؤسسة التربية الخاصية والتأهيل (SERO)

" أكاديميـة - تأهيليـة - تنمـويـة "

ترقيم دولي: ISSN2314-8608

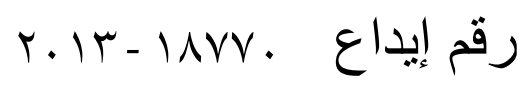

المجلد السابع - العدد السابع و العشرون - الجزءء الأول (نوفمبر، 11 . ) 


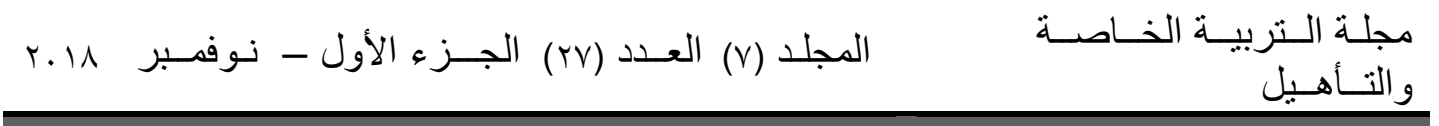

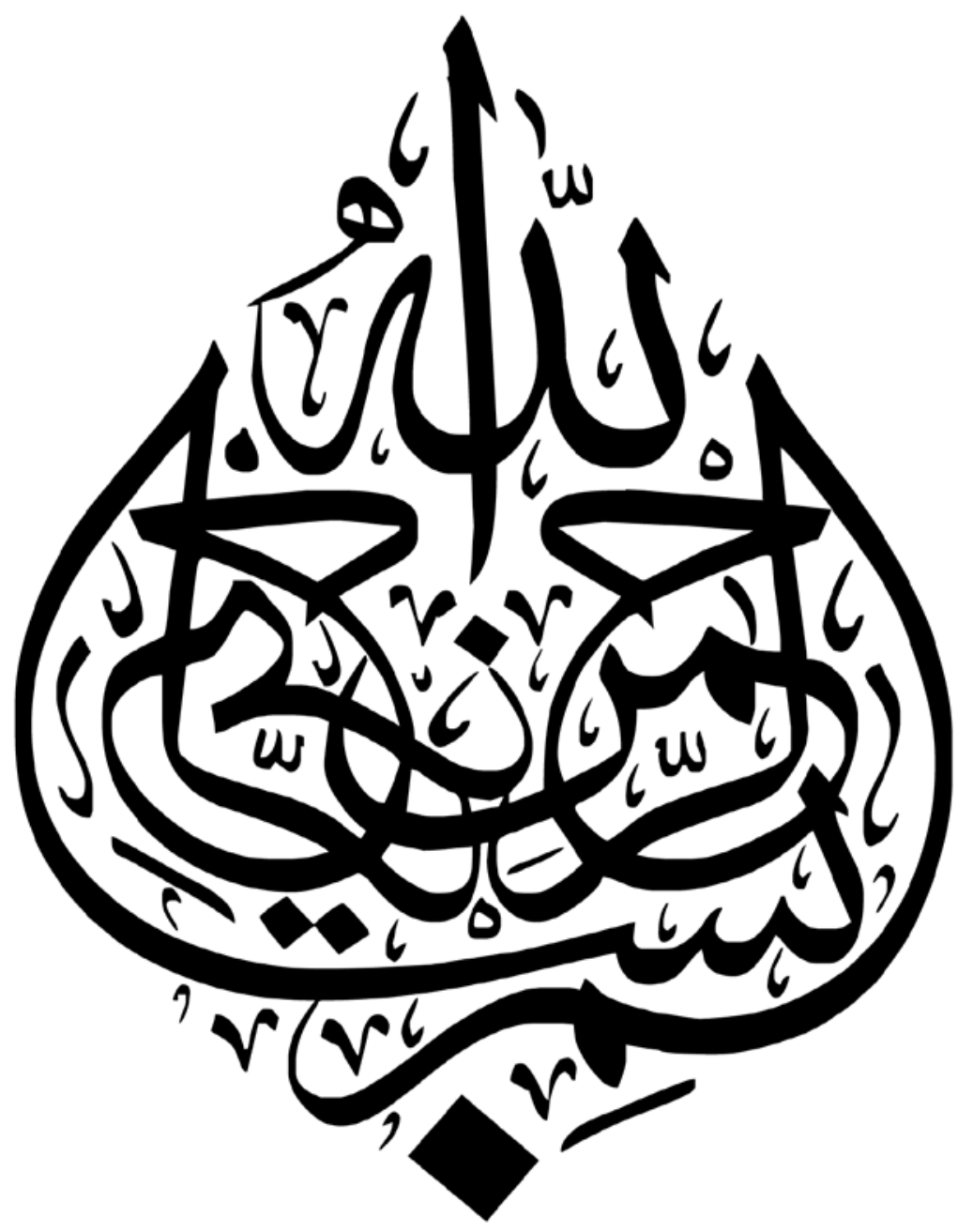




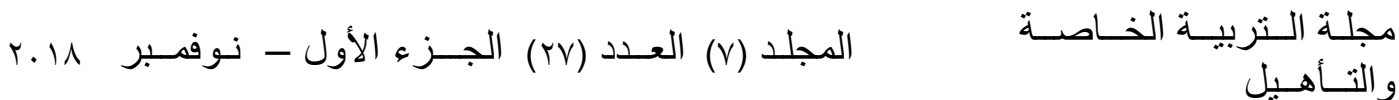

\section{الهيــــة الاستششـاربـة(*)}

أ.د/ عادل عبد الله محمد الإع

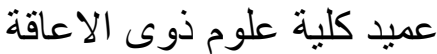

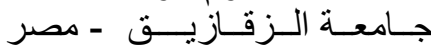

أ.د/ عبد العزيز السرطاوي الإئراتي

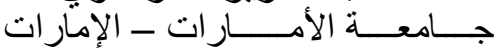

أ.د/ عبد العزيز السيد الشخص مهن

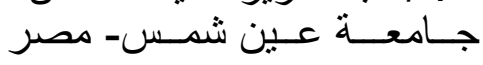

أ.دا/ عبد العزيز بن محمد العبد الجبار

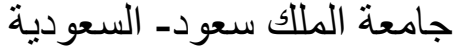

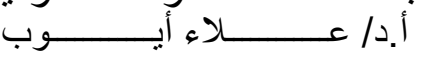

جامعة الخليج العربي- البحرين

أ.د/ ماتياس جرونكا Matthias Grïnke

جامعة كولونبا_ المانيا

\section{University of Cologne-German}

أ.د/ نـاصر بن علي الموسى أنسى

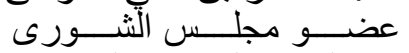

أمين عام التربية الخاصة بالسعودية سابقا

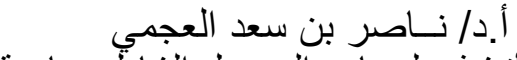

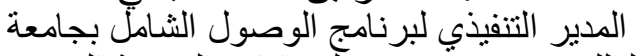

الملك سعود ورئيس مجليس إدارة الجمعية السعودية ليجية اللتربية الخاصة

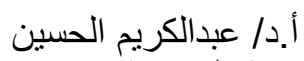

رئيس قسم التربية الخاصة - جامعة الملك الحنين

سعود

أ.د/ هارفى رود Harvey Rude

جامعة شمال كولور ادو - الو لايات المتحدة الامريكية

University of Northern Colorado-USA

$$
\text { أ.د/ أحمد عبدالعزيز التعبيمي }
$$

أ.د/ أحمد مهذى مصطفي

أستاذ علم النفس - مقرر اللجنة العملّية لترقية

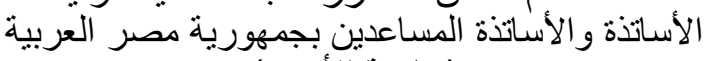

(جامعة الأزهر)

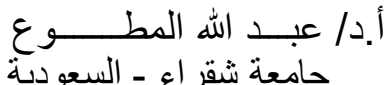

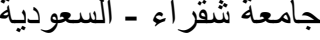

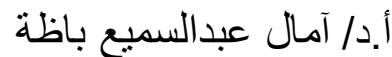

أستاذ الصحة النفسية والتربية الخاصية وعميد كلية التربية كفر الثيخ سابقا - مقرر اللجنة العلمية لترقية الأساتذة والأساتّة المساعدين بجمهورية مصر العربية لترية الأبية

$$
\begin{aligned}
& \text { أ.د/ جميل محمود الصمادي } \\
& \text { الجـامعــة الأردنيــــة ــ الأردن } \\
& \text { أ.د/ حمد بلية حمد العجمي الكوبي } \\
& \text { جامعة الكويت - الكويت العيت }
\end{aligned}
$$

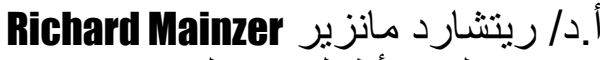
مستشار مجلس الأطفال غير العاديين الامريكى (CEC)

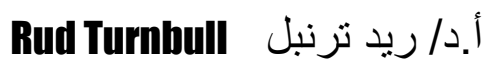

جامعة كانسس - أمريكا

$$
\text { أ.د / مديحان الرشيدي }
$$

جامعة الملك فيصل - السعودية النية

أ.د/ طارق بن صالح الريس

جامعة الملك سعود - اللسعودية الرين 


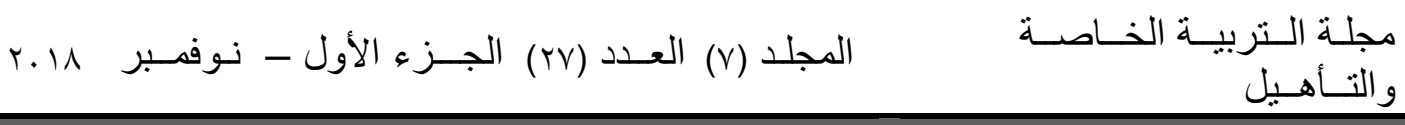

\section{هيعـة التحـرِر}

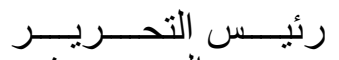

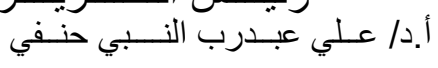

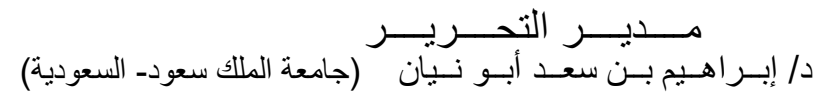

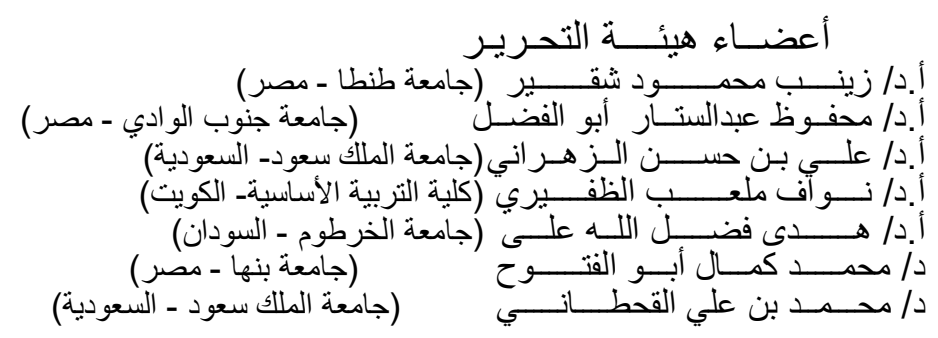

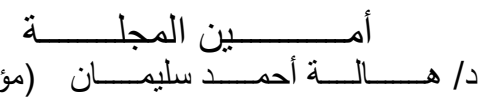

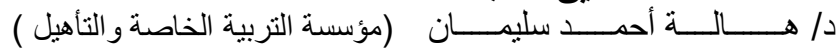

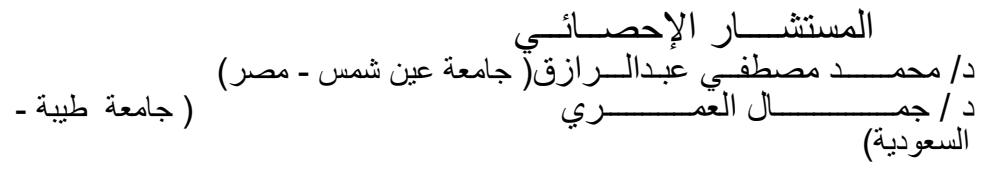

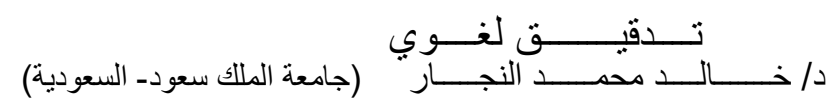

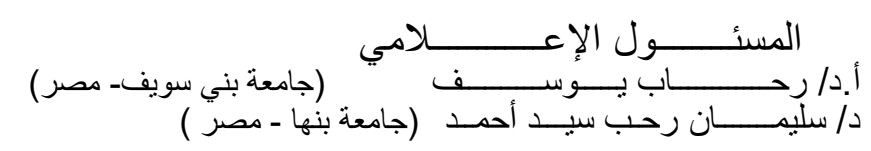

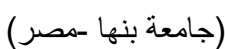

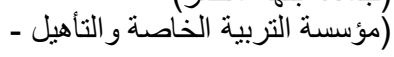

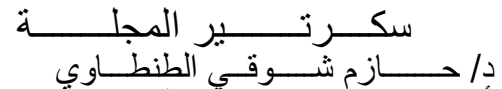

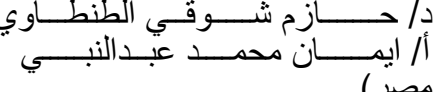




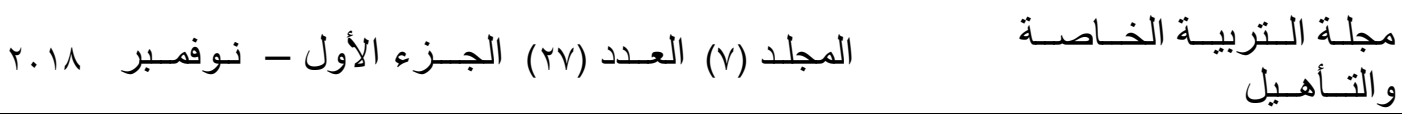

الهيئــة التنسيقيـة

\begin{tabular}{|c|c|c|}
\hline 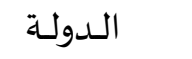 & الجــامعــة & الاســـم \\
\hline الـــــــــيمن & 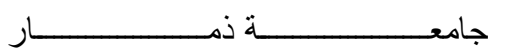 & 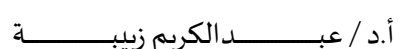 \\
\hline العــــــراق & جامعــــــــة صــــــــلاح الـــــــــــن & 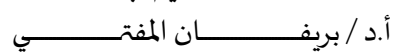 \\
\hline الســــــــدان & 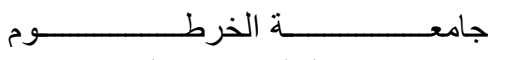 & 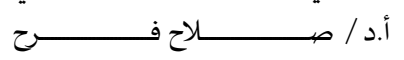 \\
\hline البحــــرين & جامعـــــــة الخـــــــــيج العربــــــــي & د / الســـــــــــد الخميبــــــــي \\
\hline الســـــــودية & 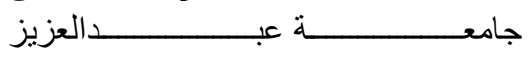 & 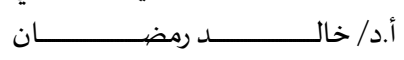 \\
\hline مصد & جامعـــة مصـــر للعــــوم و التكنولوجيــــا & 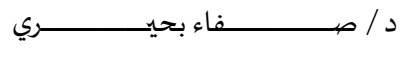 \\
\hline مصد & 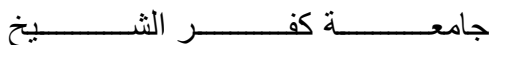 & 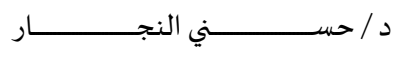 \\
\hline الجزائـــــر & 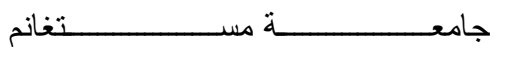 & 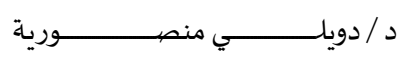 \\
\hline مصد & 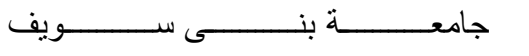 & د د /ولاء ربي \\
\hline ســــــلطنة & 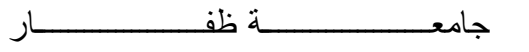 & 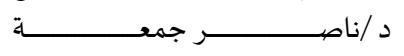 \\
\hline الاردن & 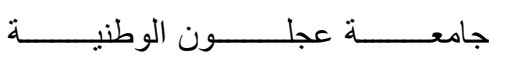 & دربــ \\
\hline الســــودية & 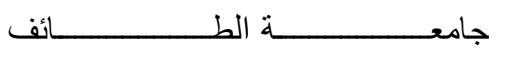 & 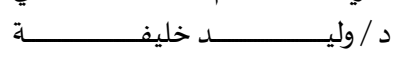 \\
\hline مصــــــر & 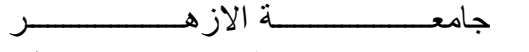 & 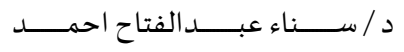 \\
\hline الســــودية & 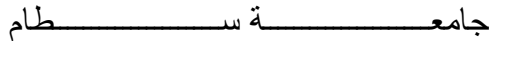 & 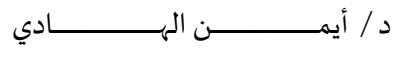 \\
\hline مصد & 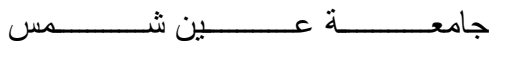 & 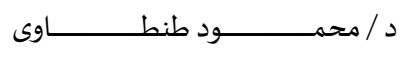 \\
\hline الســــودية & لــة الملـــــــــــــــــــــــــلـ & د/ فهــــد بـــن أحمـــــد النعـــيم \\
\hline الســـــودية & 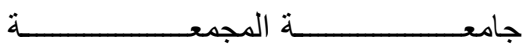 & د / منــــــي توكــــــلـل الســـــــيد \\
\hline الســــودية & لــة الملـــــــــــــــــــــلـل & دـ / عـــــــــــاطف البحـــــــــــاوي \\
\hline مصـــــر & 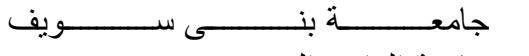 & دـ / مححمـــــود ربيــــــع الثــــــاوي \\
\hline مصر ميرة & جامعة الو ادى الجديد & د / اح \\
\hline 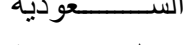 & 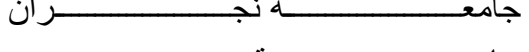 & ــــماعيل العــــــــــــي \\
\hline الســــودية & $\longrightarrow$ & 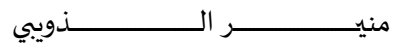 \\
\hline مص & 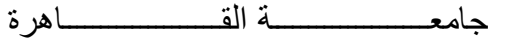 & ـيماء الســـــــــــــاعي \\
\hline الســــودية & جامعــــة الامــــام محمـــــــــــن ســـــود & 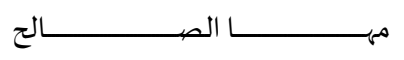 \\
\hline الســــودية & 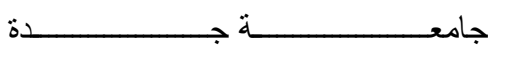 & 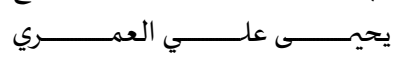 \\
\hline الســــودية & 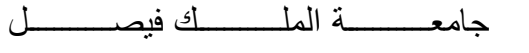 & 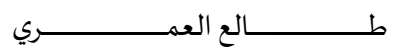 \\
\hline الكويـــــــت & مــــــــارس التربيــــــــة الخاصـــــــــة & خالــــد حمــــــــليــــة العجمهــي \\
\hline الســـــودية & 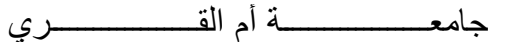 & مبــــــــــــــرك الدوســـــــــــري \\
\hline
\end{tabular}




\section{التعريف بمجلة التربية الخاصية والتأهيل}

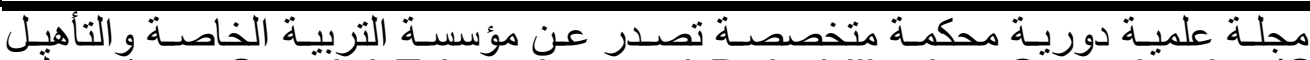
Special Education and Rehabilitation Organization(SERO)

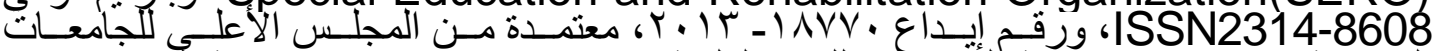

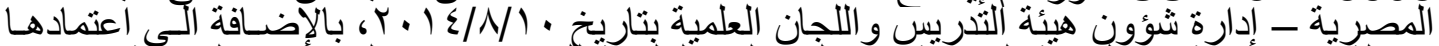

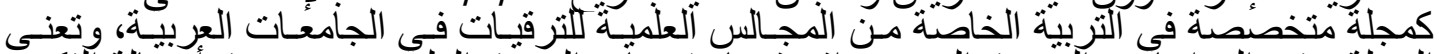

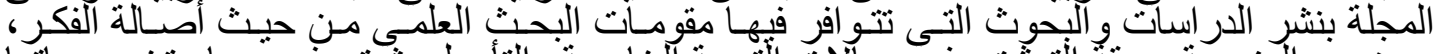

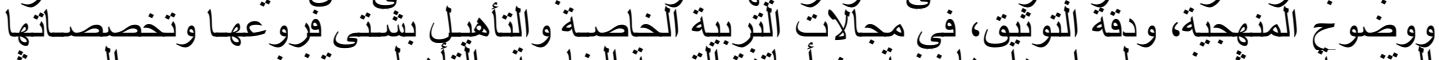

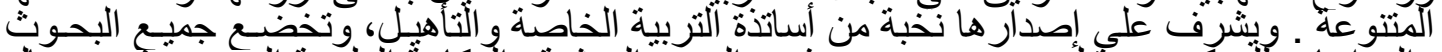

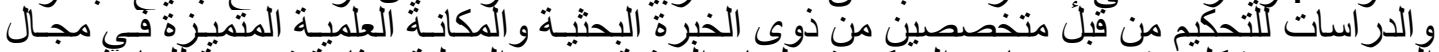

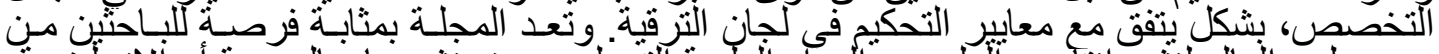

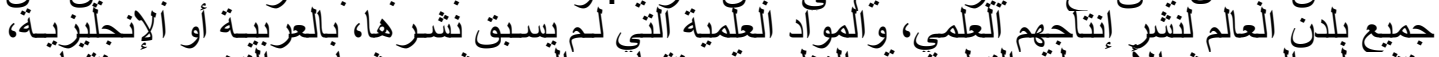

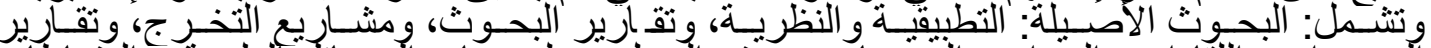

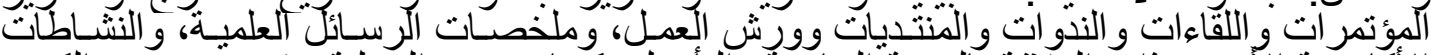

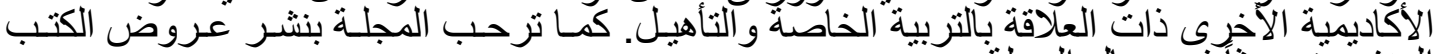

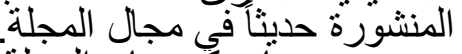

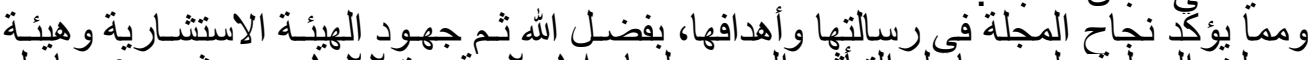

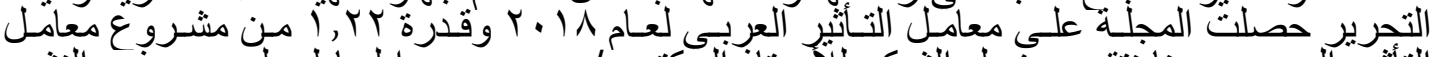

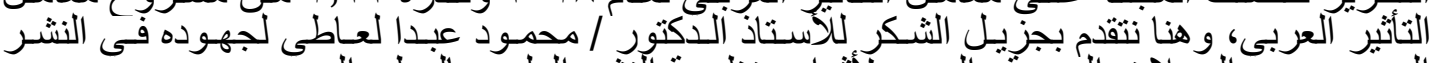

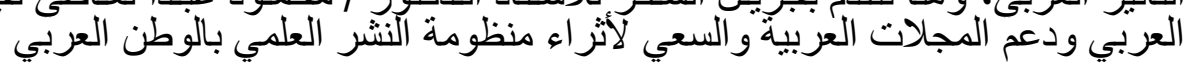

\section{رؤبســـــة المجلــــة}

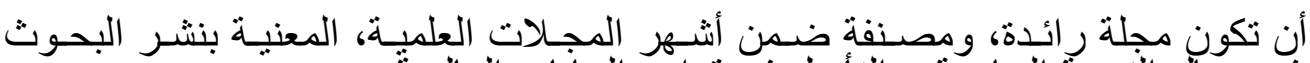

المحكمة في مجال التربية الخاصة، وندة والتأهيل في قو اعد البيانات العالمية.

\section{رســالــة المجلــة}

تسعى المجلة لتصبح مرجعًا علميًّا للباحثين، ونشر البحوث المحكمـة وفقت معـايير مهنيـة عالمية متميزة في ألتربية الخُاصنة و التأهيلّ.

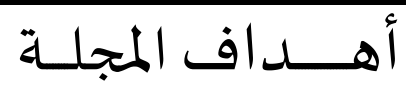

" إيجاد و عاء أكاديمي متخصص في مجال التربية الخاصة و التأهيل.

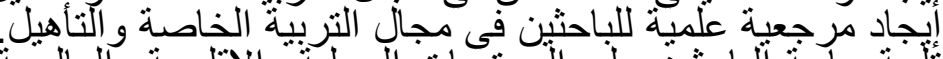

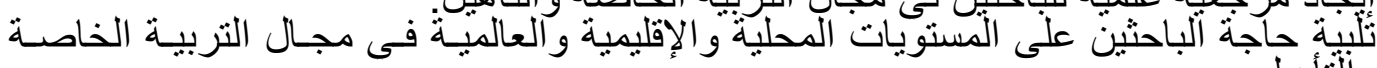
و ألتأهيل: ألمشارثيّة في بناء مجتمع المعرفة من خلال نشر أبحاث التربية الخاصة و التأهيل بعد تحكيمها من الخبر اء في التخصص. 


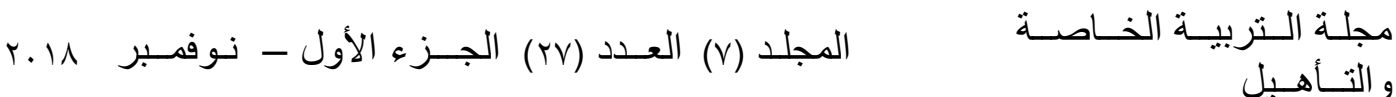

اللجنــة العلميـة|(*)

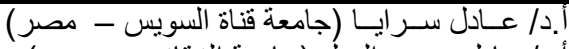

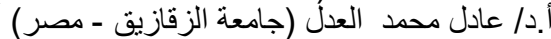

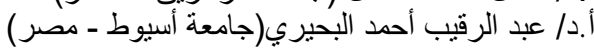

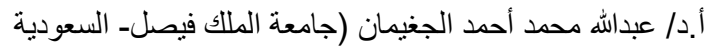

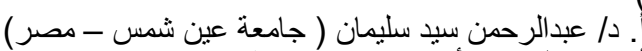

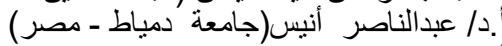
ا. ا.د/ عبدالو هاب محمد كامل (جامعة طنطا- مصر)

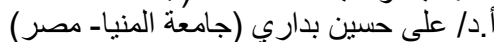

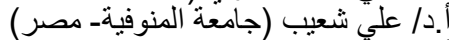

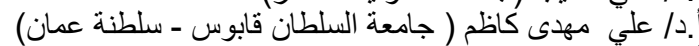

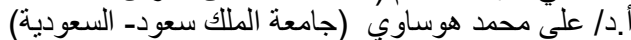
أ.د/ فاطمة محمد عبدالوهاب (جامعة بنها - مصرة)

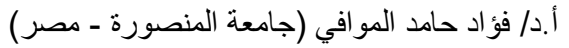

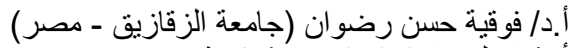

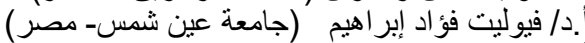

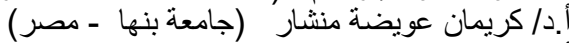

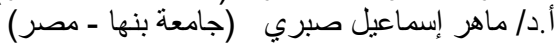

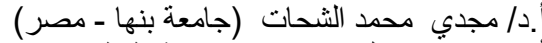
أ.د/ مجدي عبدالكريم حبيب (جامعة طنطا- مصر ) دمر)

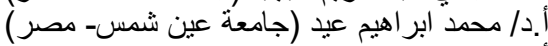

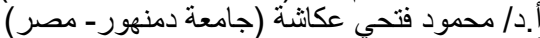

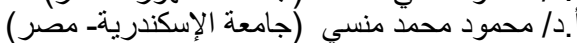

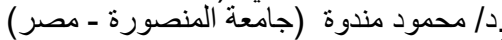

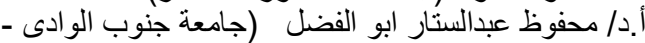

أ.د/ محمد عبد الظاهر الطيب (جامعة طنطا - مصر )

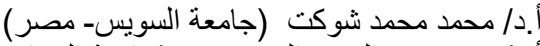

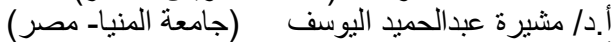

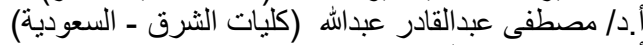

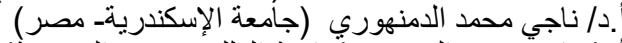
أ.د/ ناصر سعد العجمي (جامنامعة الملك سعودـ- السعودية)

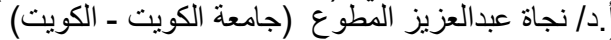

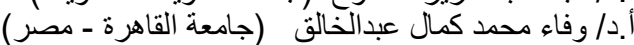

أ.د/ هشام عبدالرحمن الخولى ( جامعة بنها - مصر )

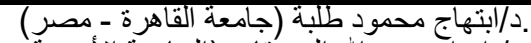

إ.د/ إبر اهيم عبداله الزريقات (الجامعة الأردنية ــ الأردن)

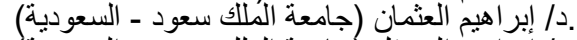

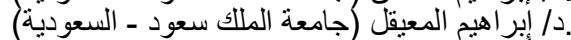

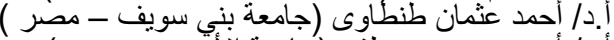

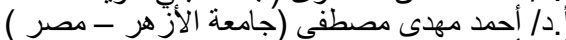

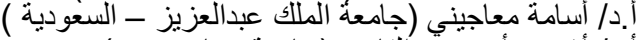

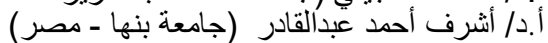

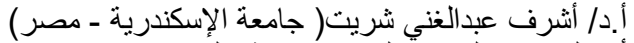

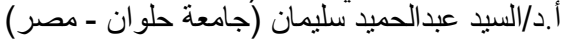

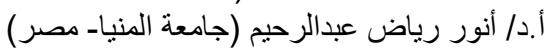

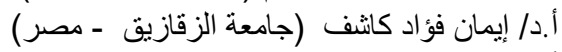

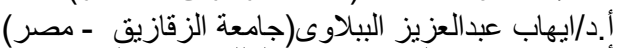

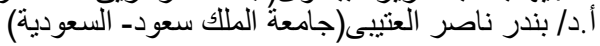

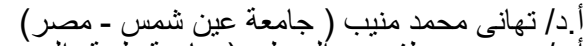

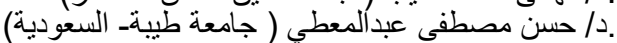

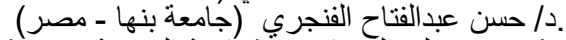

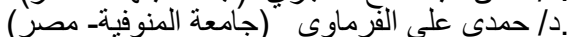

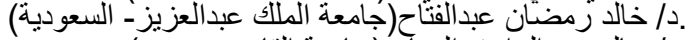

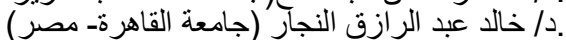

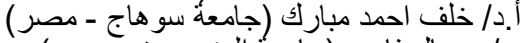

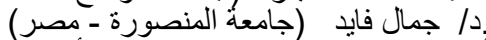

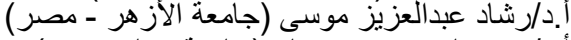

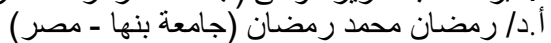

أ.د/ زيد محمد البتال(جامعة الملك سعودـ- السعودية) أ.د/ زيدان السرطلاوى(جامعة الملك سعود- السعودية)

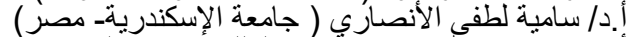
أ.د/ سعيد عبد الله دبيس (جامئمعة الملك سعود - السعودية)

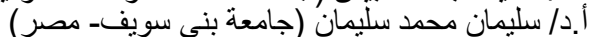

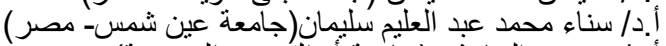

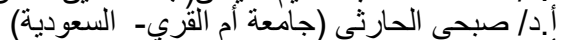

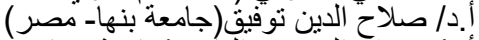

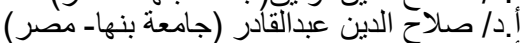

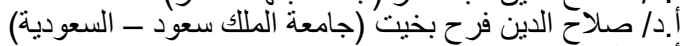

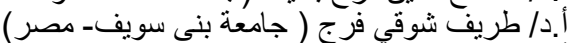

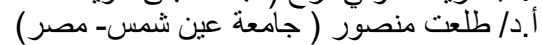

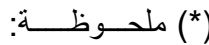
ا ـ تم ترتيب الأسماء حسب الأب الأبجدية.

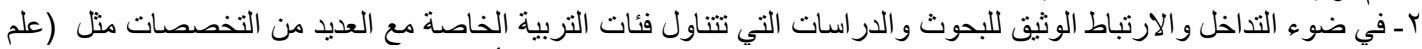

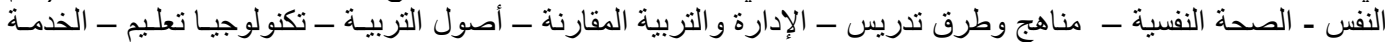

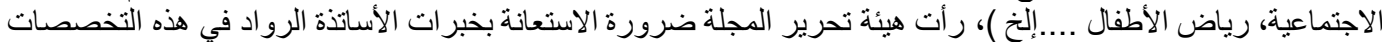




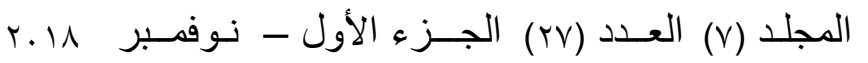

مجلـة الــتربيـة الخــاصــة

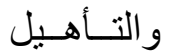

\section{قـواعـد النششــر}

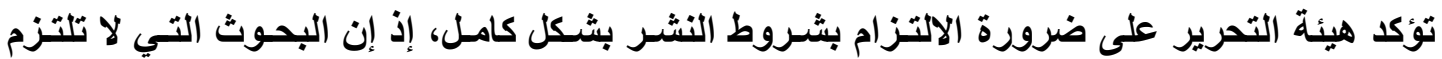

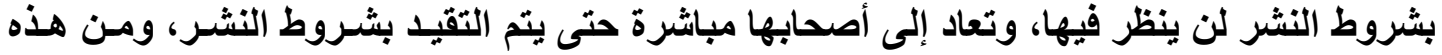

7- ت تدرج الجداول في النص وترقم ترقيماً منسلسلاً وتكتب عناوينها أما الملاحظات التوضيحية فتكتب تحت الجدول.

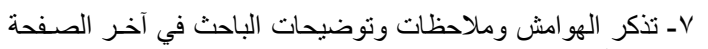

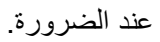

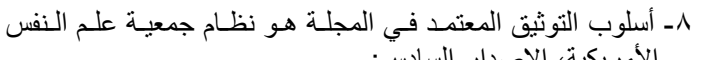
(الأمريكية، الإصدار السادس:

(American Psychological Association- APA-6th ED)

9ـ لهيئة التحريـر حق الفحص الأولـي للبحث، وتقريـر أهليته، أو رفضه للنشر.

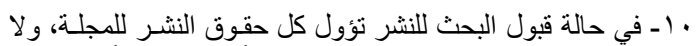

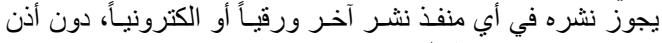
كتابي من رئيس هيئة التحرير.

11 - في حالة نشر البحث، يعطي الباحث نسخة من المجلة، وعدد (0) متسلّسلات من الدر اسة.

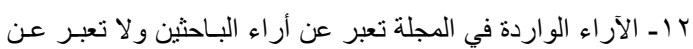

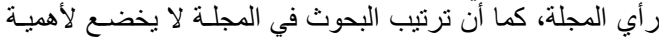

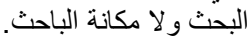

با - يتم تقديم البحوث الكترونياً على برنامج Word من خلال البريد

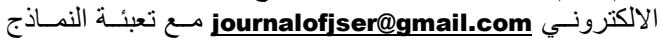

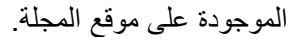

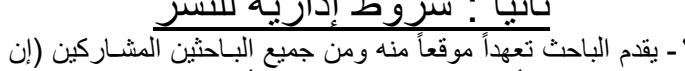

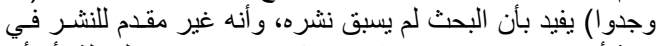

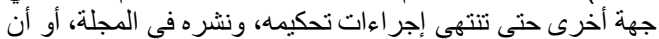

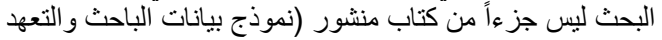

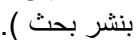
r- لا يجوز نشر البحث أو أجز اء منه في مكان آخر، بعد إقرار نشره

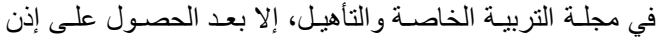
كتابي بذللك من رئيس التحرير.

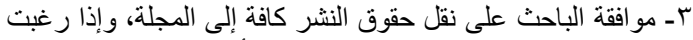

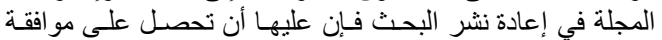

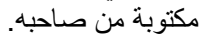

ولمزيد من المعلومات : يرجى الدخول على الموقع الالكتروني التالي: http://sero.org.eg

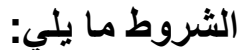

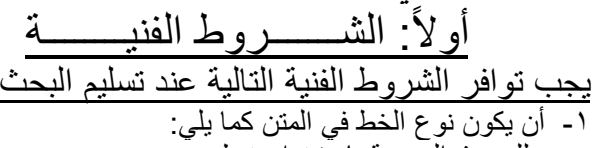

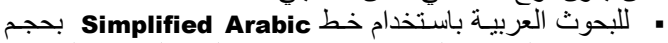

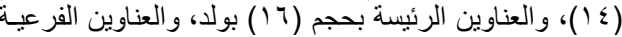

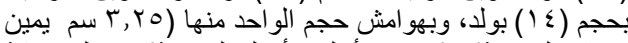

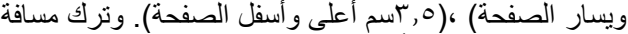

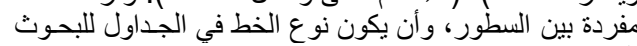
العربية Simplified Arabic بحجم ( • (1).

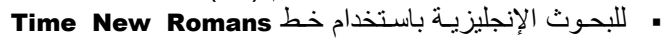

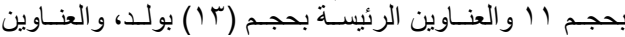

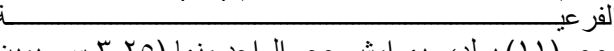

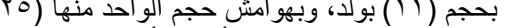

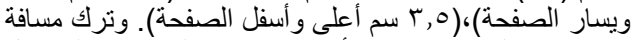

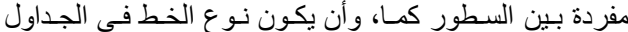

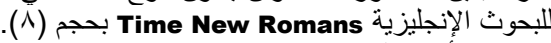

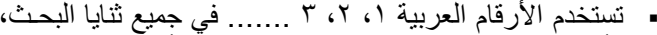
وأن يكون ترقيم صفحات البحث في منتصف أسفل الصفحة.

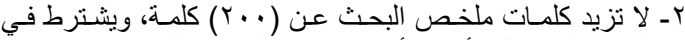

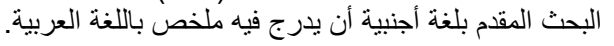

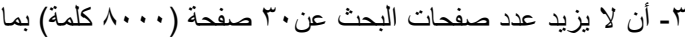

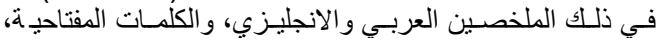

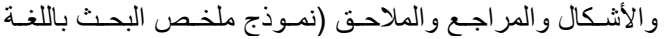
العربية واللغة الانجليزية).

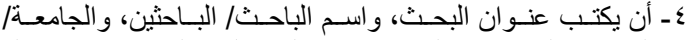

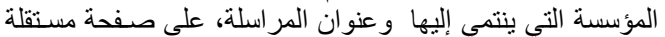

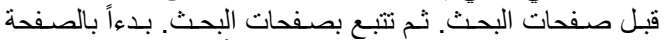
الأولى حيث يكتب عنوان البحث فقط متبو عاً بكامل البحث .

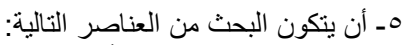

مقدمة ،مشكلة الدراسة وأسئلتها/ فرضياتها، ثم أهدات أهدافها، ثم أهميـة

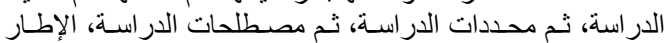

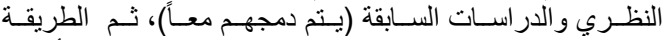

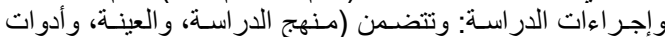

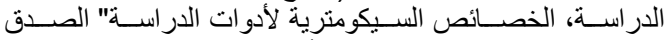

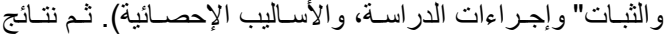

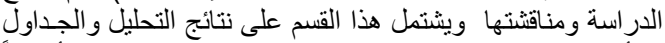

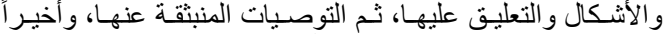

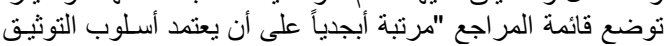

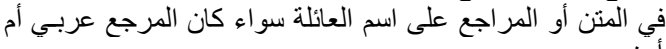




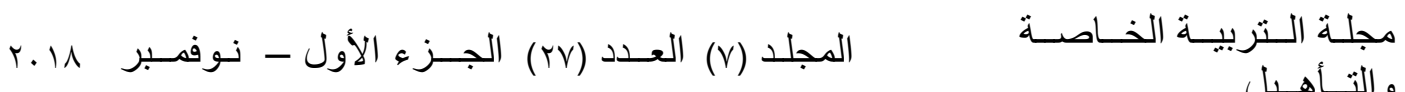

$$
\begin{aligned}
& \text { المراسـالات }
\end{aligned}
$$

ترسل البحوث وجميع المراسلات المتعلقة بالمجلة إلى البريد الالكتروني للمجلة:

\section{journalofjser@gmail.com}

• أو إلي رئيس هيئة تحرير مجلة التربية الخاصة و التأهيل:

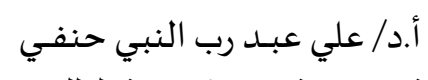

كلية التربية - جامعة بنها ( جامعة الملكا سعود سابقا)

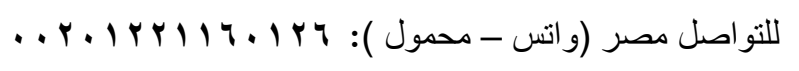

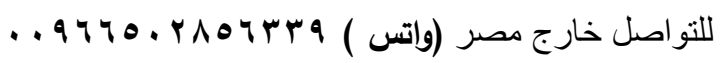

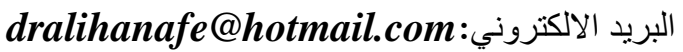

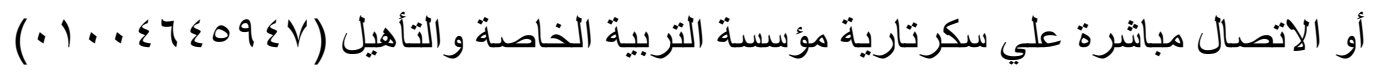

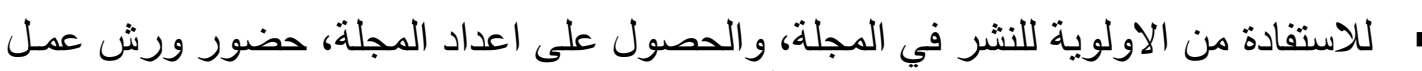

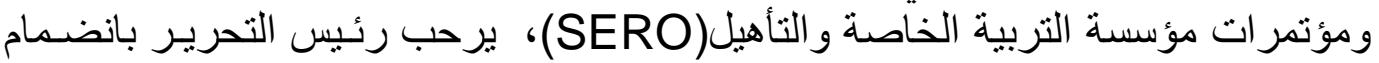

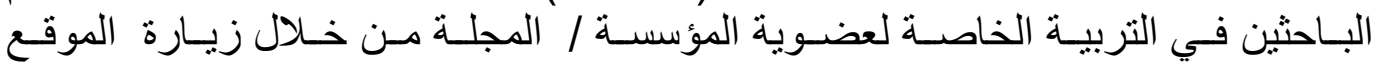
http://sero.org.eg الالكثروني اللمجلة

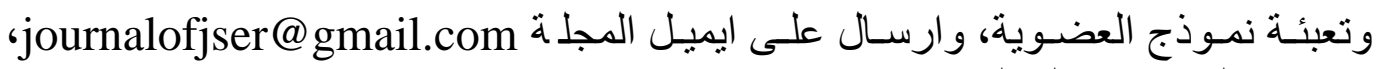
وحساب المؤسسة بينك التعمير و الاسكان فرع بنها (0180000012150). 


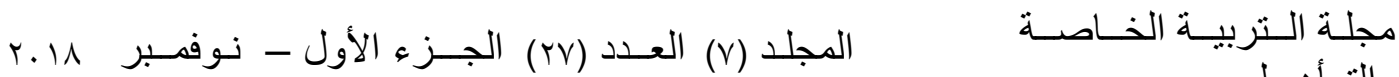

$$
\begin{aligned}
& \text { و التـأهـيل لـيل } \\
& \text { محتــوبـات العــدد }
\end{aligned}
$$

\section{الصفحة}

\section{العنـــــــــوان}

ي

افتتاحية العدد (رئيس هيئة تحرير المجلة). .

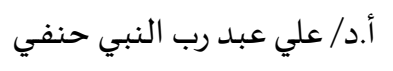

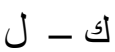

\begin{tabular}{|c|c|}
\hline & الأبي \\
\hline$r \leqslant-1$ & 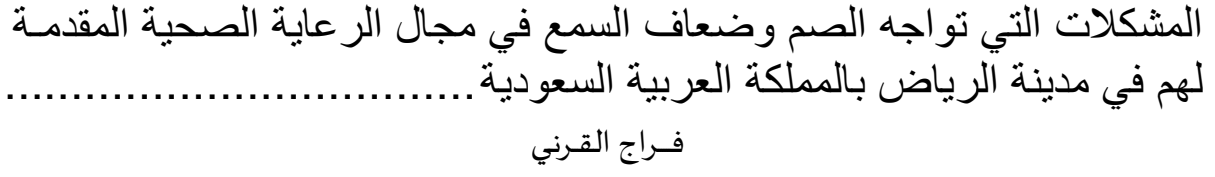 \\
\hline $79-10$ & 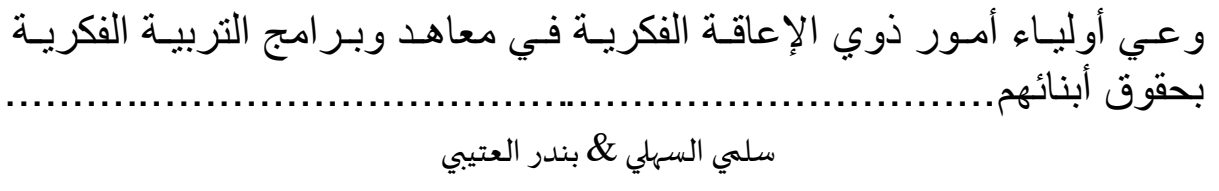 \\
\hline $\mid r r-V I$ & 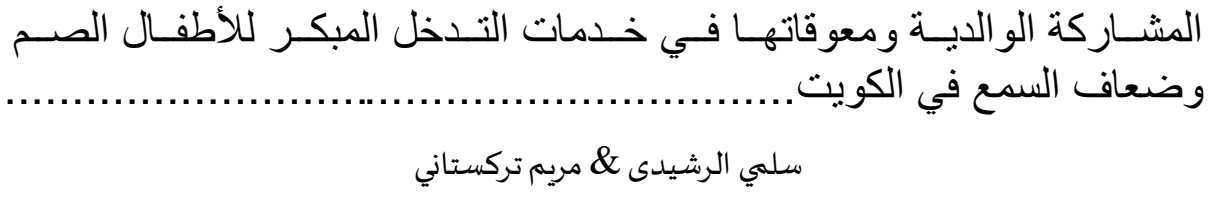 \\
\hline $170-14 r$ & 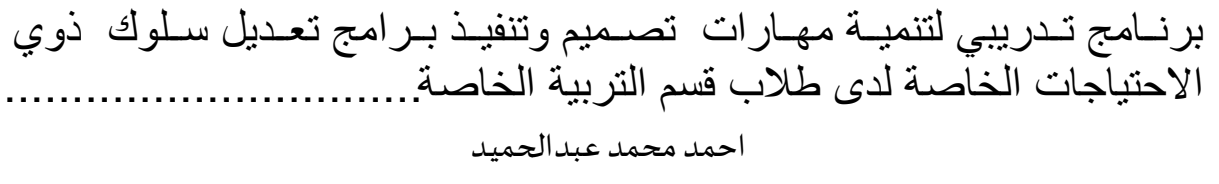 \\
\hline $\begin{array}{c}-17 r \\
r+1\end{array}$ & تقرير المصير لدى التلاميذ ذوي الإعاقة الفكرية ومعوقات اكتسابه .................... عذارى العتيبي \\
\hline
\end{tabular}
تقديم العدد .

أ.د/ محمود مندوه محمد سالم 


\section{افتتـاحيــة العـدد}

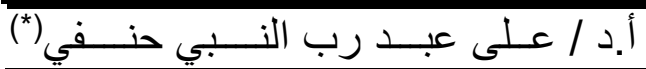

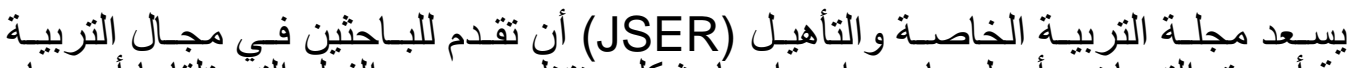

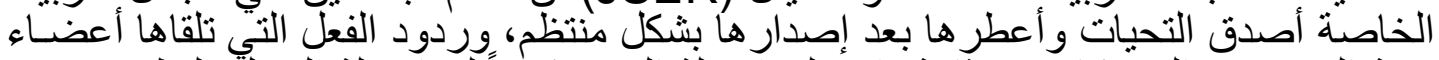

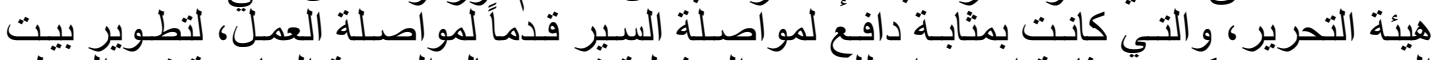

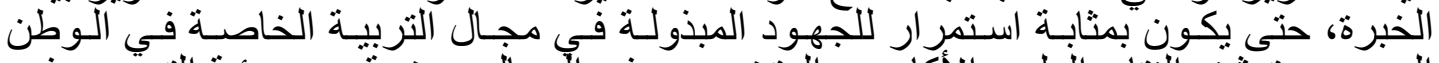

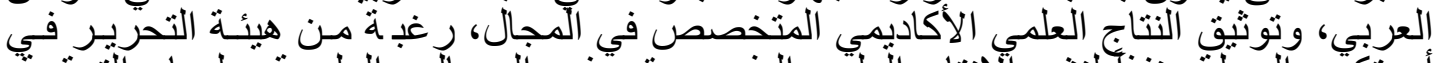

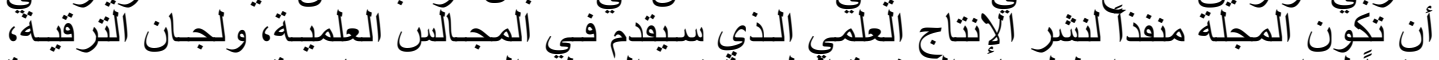

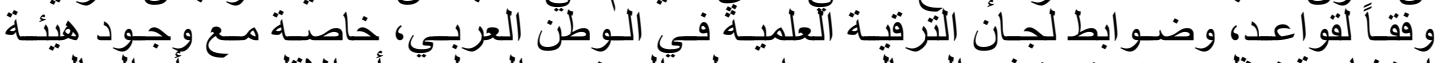

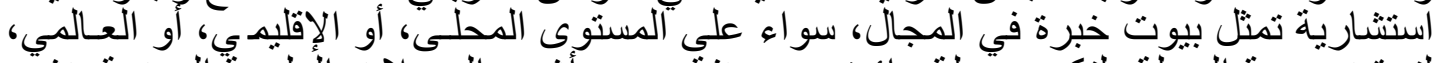

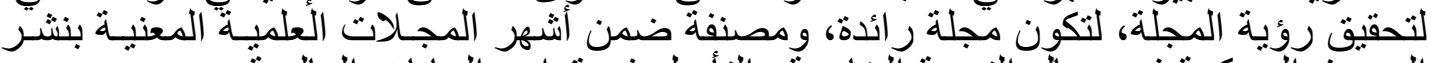

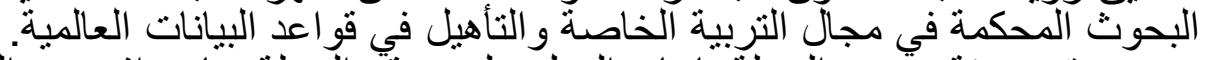

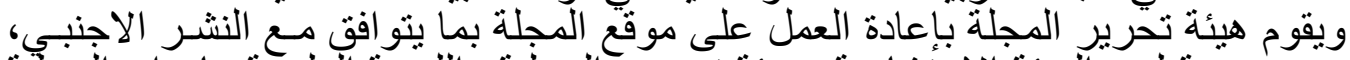

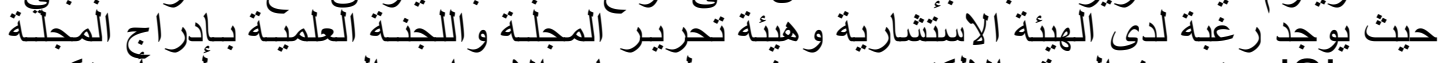

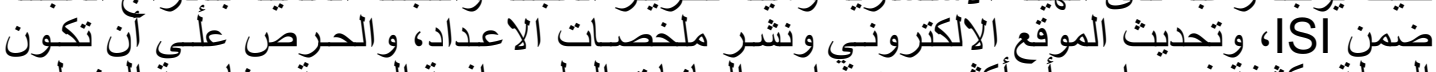

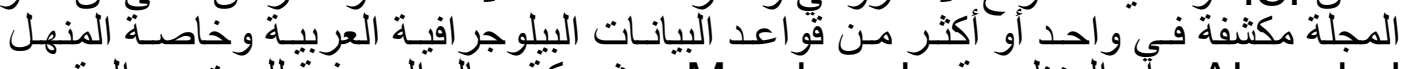
Almanhal

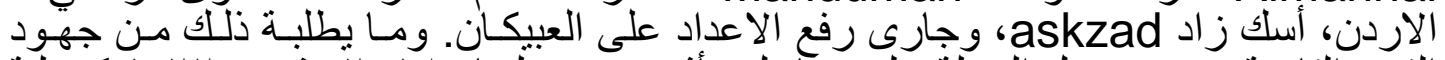

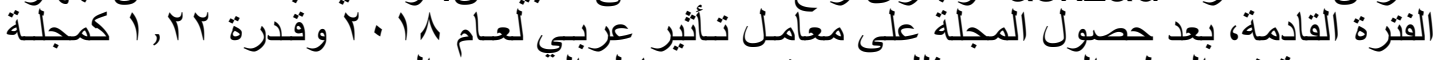

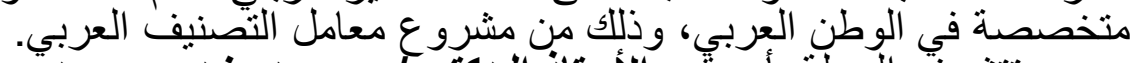

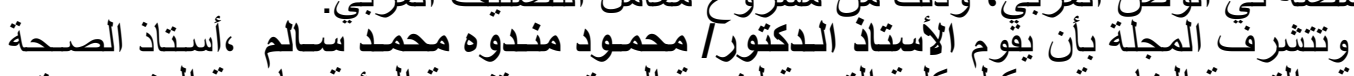

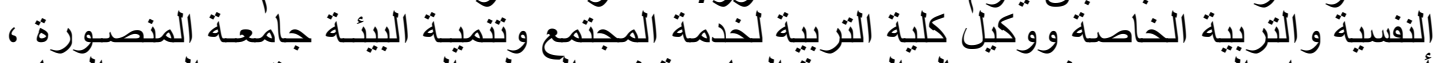

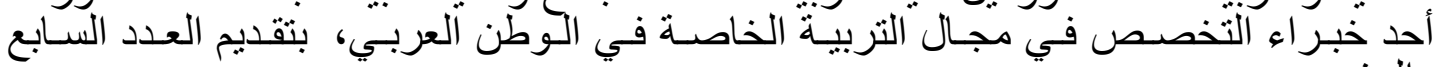

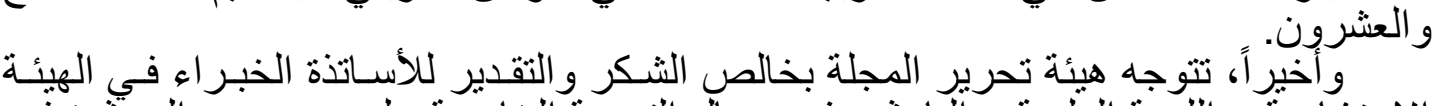

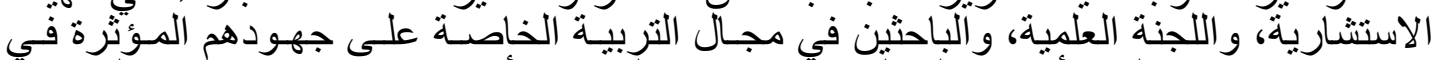

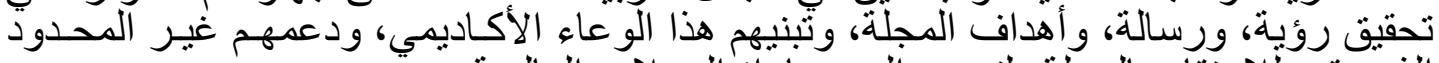

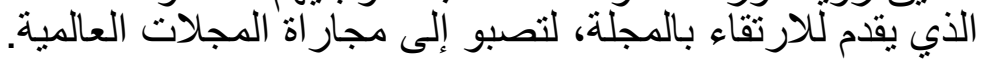
تحياتي وتقديري،،6، 


\section{تقـــــم العـدد}

أ.د/ محمود مندوه محمد سالم (*)

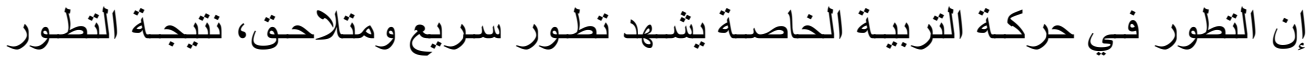

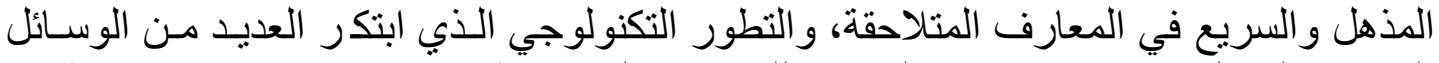

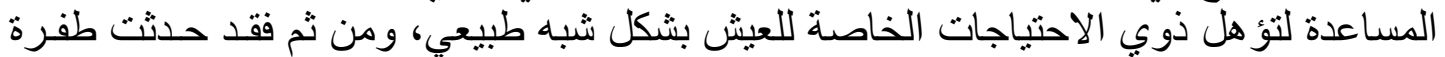

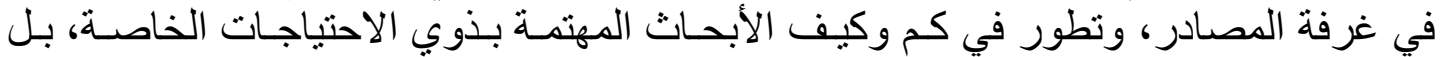

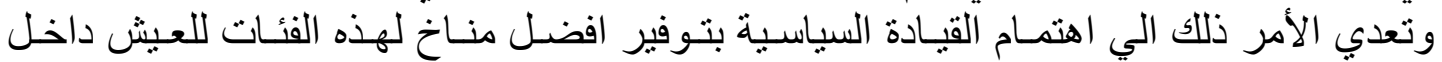

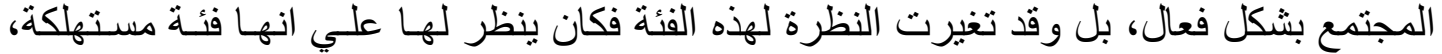

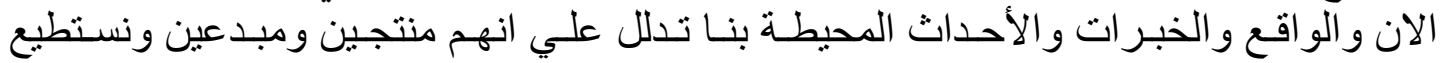

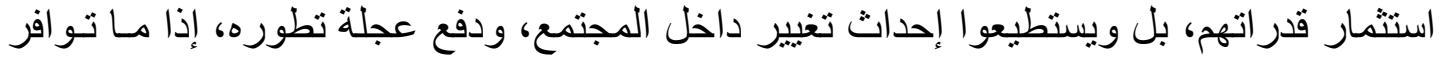

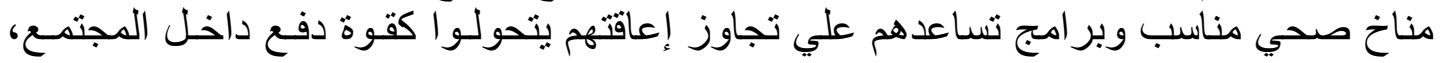

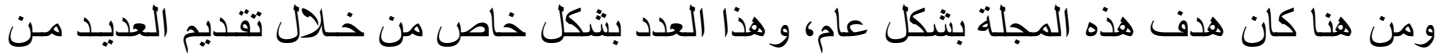

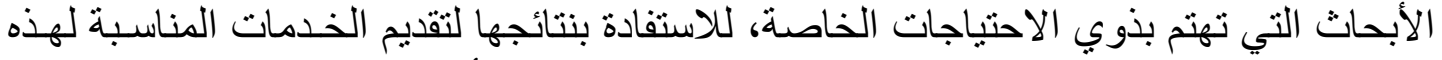

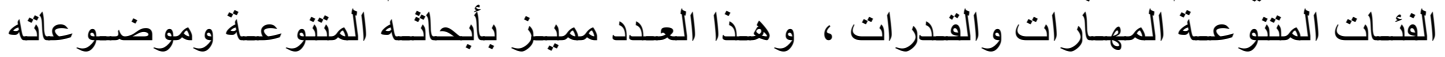

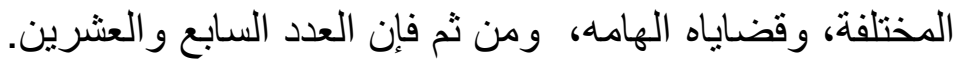

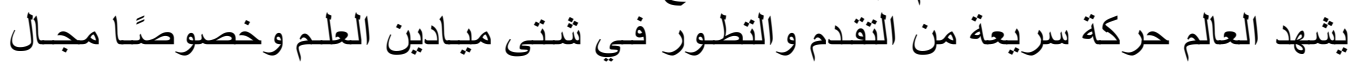

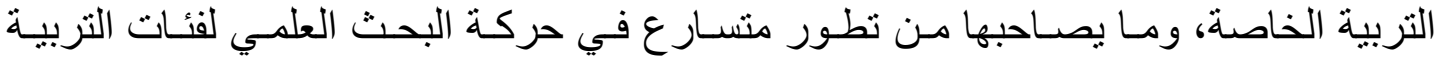

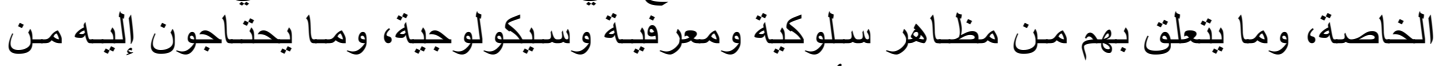

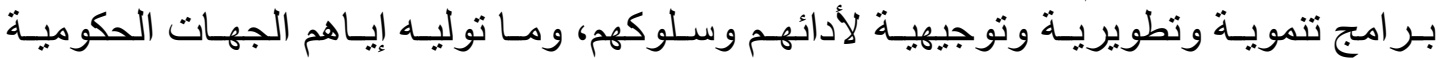

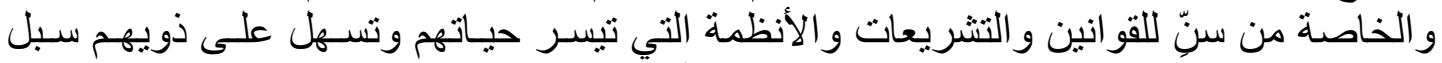

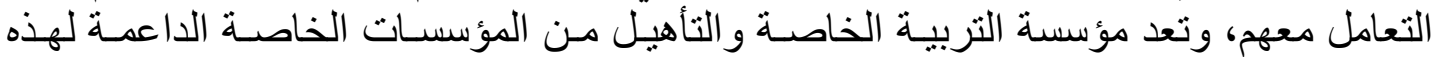

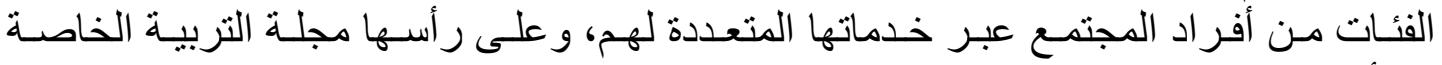

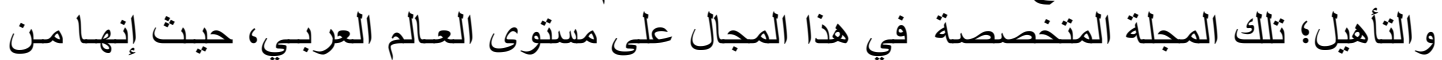

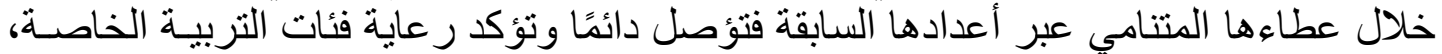

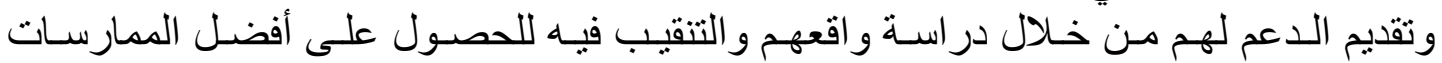
المناسبة لهم باختلاف فئاتهم وتصنيفاتهم.

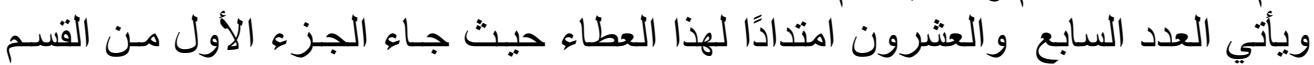

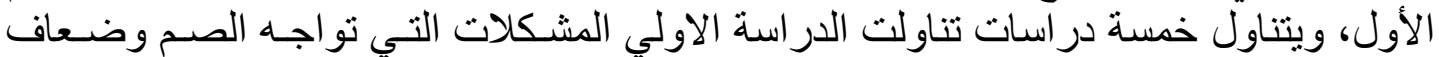

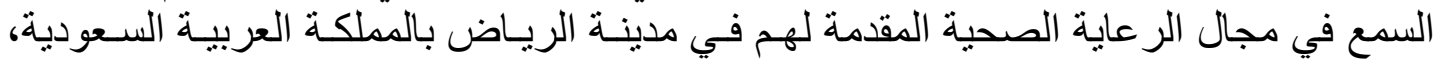

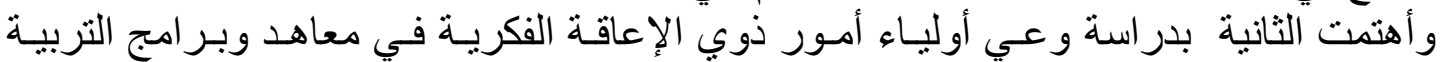

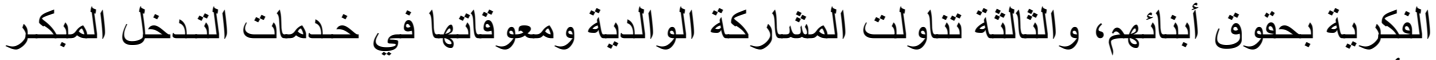

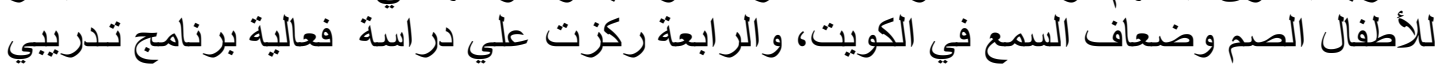

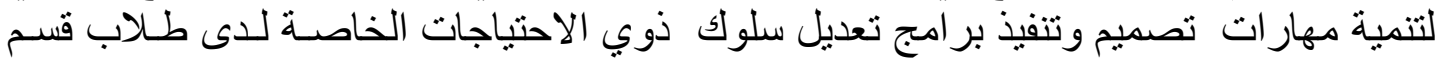




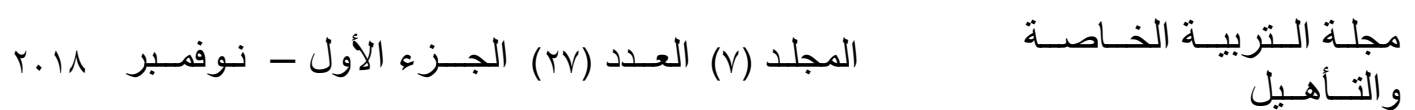

التربية الخاصة، و الخامسة ناقشت تقرير المصبر لدى التلامبذ ذوي الإعاقـة الفكريـة ومعوقـات

اكتسابه .

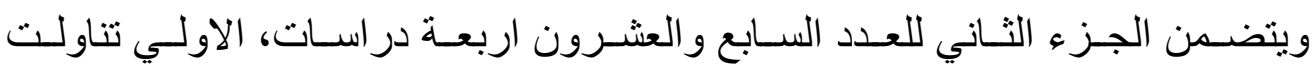

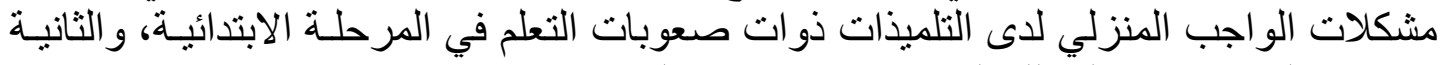

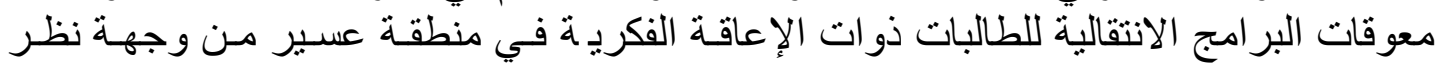

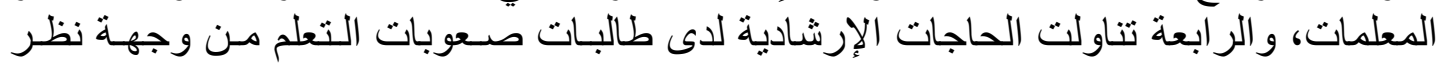

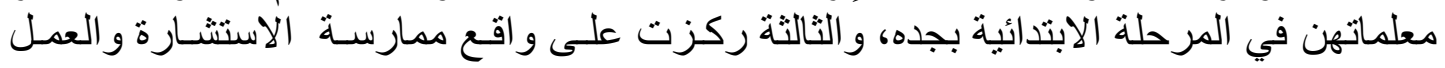

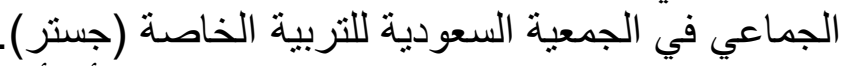

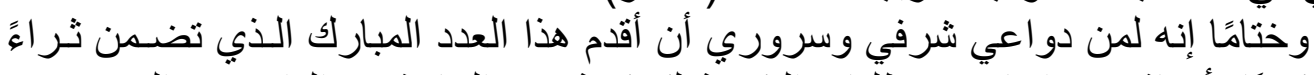

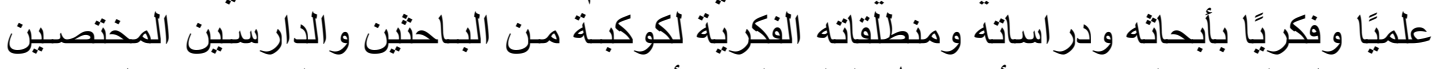

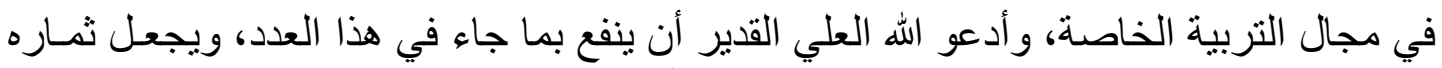

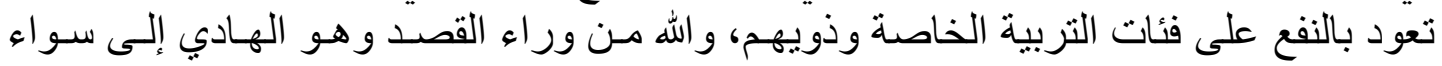

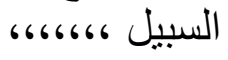

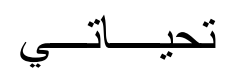

$$
\text { أ.د/ محمود مندوه محمد سالم }
$$

